\title{
Analysis of Indonesian Men's Apparel Exports to Seven Countries in Europe Union
}

\author{
Sri Mulatsih \\ Department of Economics \\ Bogor Agricultural University \\ Bogor, Indonesia \\ mulatsupardi@gmail.com
}

\author{
Rizkia Nurfrina Putri \\ Department of Economics \\ Bogor Agricultural University \\ Bogor, Indonesia \\ rizkia.nurfrina@gmail.com
}

\begin{abstract}
Mens-apparel is a potential export product from Indonesia textile industry. There is a potential increase in this product to European Union (EU). The presence of an exporting country competitor i.e., Vietnam, becomes a challenge for Indonesia to maintain its market position. The aims of this study are to describe the general condition of mens-apparel export to seven EU countries, to analyze its competitiveness using Revealed Comparative Advantage (RCA), and to determine factors that affect its exports. The result of RCA analysis showed that Indonesia has a comparative advantage, in spite of the competitiveness, which has gone farther than Vietnam. While, the result from the EPD (Export Product Dynamic) analysis showed that the market position is rising star in Italy and Poland, while in Germany, France, Belgium the market position is Falling star, and Retreat in Spanish. Real Gross Domestic Product (GDP) per capita of destination country, real effective exchange rate, exports price and quality of port infrastructure have positive effect on the value of exports, while the economic distance variable has negative effect.
\end{abstract}

Keywords: Competitiveness, EPD, gravity, man apparel, RCA.

\section{INTRODUCTION}

Indonesia's exports in 2014 were dominated by the nonoil and gas sector contributing 82.94 percent of the total exports, while 17.06 percent was from the oil and gas sector [1]. Figure 1 shows that during the period of 2010-2014, the non-oil and gas sector exports tended to be stagnant and increased in 2011, yet decreased until 2014. The average growth of non-oil and gas exports for five years has amounted to 5.7 percent. The Economic Crisis in the United States and the European Union became one of the causes in the decline of Indonesian non-oil exports. Nevertheless, the manufacture product can still be the main export, contribute 77.9 percent to non-oil and gas export in 2014 [1]. One of ten main export commodities from Indonesia is textile commodity. In 2010-2014, the highest export from textile industry was mens-apparel, contributing 51.63 percent accompanied by 1.49 percent export growth. While yarns and fabrics amounted to 20.33 and 14.60 percent respectively.

The EU market is a traditional markets for apparel export other than Japan, Canada, USA and Uni-Emirate Arab (UEA). However, the volume of Indonesian's mens-apparel exports was fluctuating and even tended to decline in the EU countries. The Netherlands, Italy, and France are the countries that have decreased the value of their importing mens-apparel from Indonesia. The decline in the export of mens-apparel has become a phenomenon that needs to be considered to survive in the traditional markets.

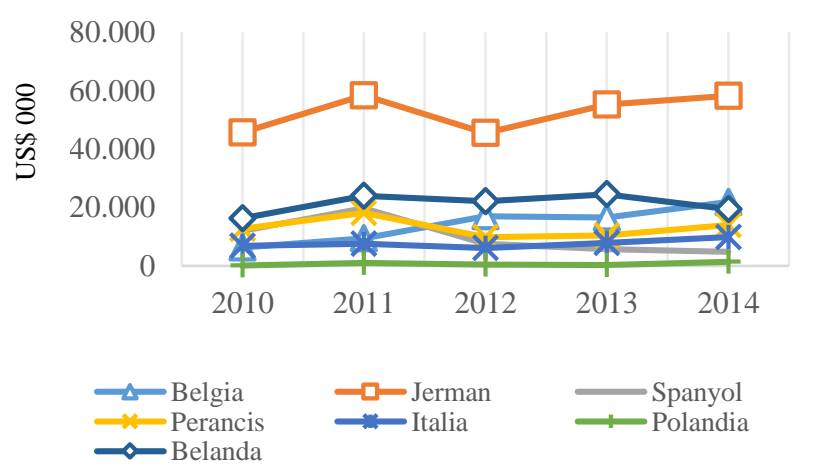

Source: UNCOMTRADE, 2017

Fig. 1. Value of mens-apparel Indonesia exports to major destination countries

Fig. 1 shows that the mens-apparel exports in Germany, Belgium, France, Italy and Poland was still increasing after the EU crisis in 2011-2013, especially in Belgium which increased US \$ 5,366 thousand during 2013 to 2014. The EU market contributed 26.53 percent greater than other major export destination countries such as Japan, Korea and Canada which values are only 9.18, 4.32, and 1.94 percent respectively. These countries also have positive economy growth (1.2 percent) after the crisis, and have a large total population of 320,856 million people in 2014 .

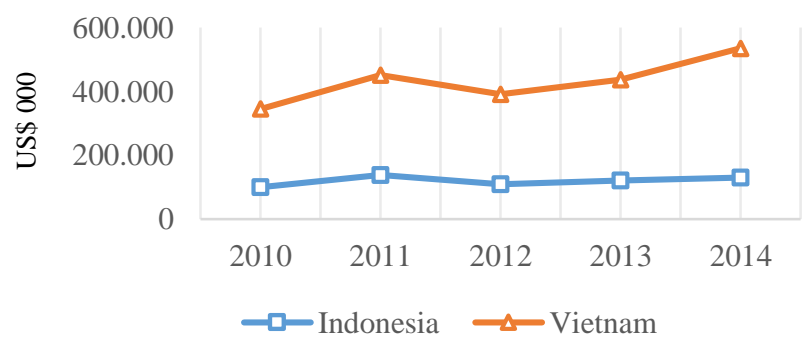

Source: UNCOMTRADE 2017

Fig. 2. Value of Indonesian and Vietnam men's apparel exports

Vietnam is one of Indonesia's strongest competitors in mens-apparel exports. Although it has similar economic conditions with Indonesia, Vietnam ranks as the fifth largest 
exporter of mens-apparel in Southeast Asia, while Indonesia ranks sixteenth. The average of Vietnam export growth was 14.5 percent during 2010-2014 (Fig. 2), while Indonesia was only 8.8 percent. In 2014 , the difference between the export's value of men clothing exports between Indonesia and Vietnam is US \$275,778 thousand.

The purposes of this research are to analyze the comparative and dynamics competitiveness of Indonesia's and Vietnam's mens-apparel exports to the seven EU countries and analyze the factors affecting the export of Indonesian men's apparel to the seven EU countries.

\section{RESEARCH MethodOlOGY}

This study uses annual panel data from seven countries in Europe (Belgium, Netherlands, Germany, Italy, France, Spain, and Poland) in series data from 2010 to 2014. Export data are from [2], DGP and Quality Infrastructure index from [3], Real exchange rates from [4] and geographical distance from [5]. Methods of analysis are Revealed Comparative Advantage (RCA), Export Product Dynamic (EPD), and Gravity Model.

RCA was used to measure the competitiveness of export products [6] using the formula (1):

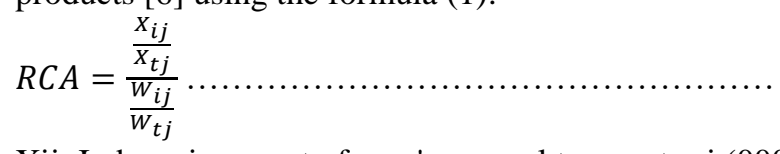

Xij: Indonesia export of men's apparel to country j (000 US\$)

$\mathrm{Xt}$ : Total of Indonesia export to country j (000 US\$)

Wij: world export of mens-apparel to country j (000 US\$)

Wt: Total of world export to country j (000 US\$)

EPD is used to determine the dynamics of commodity export based on indicators of business strength (X) and market attractiveness (Y) in export destination countries [7]. Business strength is measured with market share (2), while market attractiveness is measured with market demand growth (3).

$X=\frac{\sum_{t=1}^{t}\left(\frac{\mathrm{Xij}}{W i j}\right) t \times 100 \%-\sum_{t=1}^{t}\left(\frac{X i j}{W i j}\right) t-1 \times 100 \%}{T} \ldots \ldots \ldots \ldots \ldots$

$Y=\frac{\sum_{t=1}^{t}\left(\frac{\mathrm{Xt}}{W t}\right) \mathrm{t} \times 100 \%-\sum_{t=1}^{t}\left(\frac{\mathrm{Xt}}{W t}\right) t-1 \times 100 \%}{T}$

Where, $\mathrm{t}$ is the year and $\mathrm{T}$ is number of year analysis.

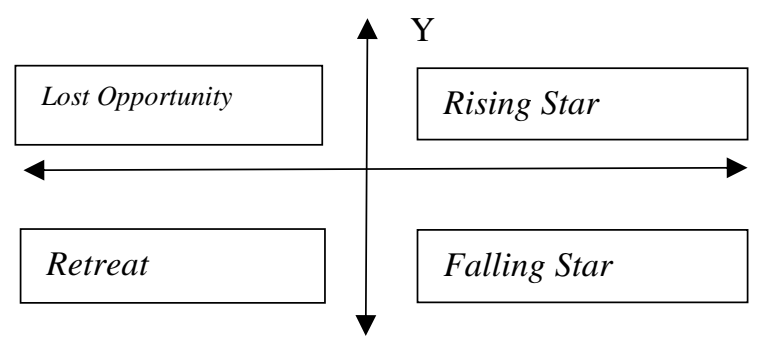

Fig. 3. Matric of EPD

There are four categories of position in the commodity export dynamics i.e. Rising Star, Falling Star, Lost Opportunity, and Retreat (Fig. 3).
The third method was gravity model (4) developed by [8]. In the trade context, the intensity of inter-state trade will be positively related to the national income of each country and is inversely related to distance. A country with a large (number of) population and rich (wealthy country) has higher of trade compared to a smaller one. The distance between countries affects the trade as well, but it does not inhibit the trade. The panel data were used in the gravity model (4), because of several advantages [9] i.e. the size of observation was bigger, reduce collinearity, better in controlling heterogeneity and dynamics of adjustment. There are three panel data models i.e. Pooled Least Square (PLS), Fixed Effect Model (FEM), and Random Effect Model (REM) [10]. Chow test and Hausman test were used to select the proper model.

$\operatorname{LnEX}_{i j t}=\alpha+\beta_{1} \operatorname{LnGDPcap}_{j t}+\beta_{2} \operatorname{LnREER}_{j t}+$ $\beta_{3} L n E D_{i j t}+\beta_{4} L n P E X_{i j t}+\beta_{5} L n Q P I_{i t}+\mu_{t}$

Where, $\mathrm{EX}_{\mathrm{ijt}}$ is the value of Indonesian men apparel exports to the seven countries which are the member of EU in year $t$ (US\$), GDPcap $\mathrm{j}_{\mathrm{jt}}$ : Real GDP per capita (US\$), REERjt: Real effective exchange rate (destination country/US\$), $E D_{\mathrm{ij}}$ : Economic distance, $\mathrm{PEX}_{\mathrm{ijt}}$ : Export price (US\$/ton), $\mathrm{QPI}_{\mathrm{it}}$ : Quality of port infrastructure (scale 1-7), $\mu_{\mathrm{t}}$ : error term, $\alpha$ : Intercept, $\beta \mathrm{n}$ : slope Ln: logarithm natural, i: Indonesia, $\mathrm{j}$ : destination country.

\section{RESULT AND DISCUSSION}

Export activity can provide profit, increase the national income, and increase the output and economic growth rate [11]. This research focused in mens-apparel product with code HS 6203 consisting of suits, jackets, blazers and pants. In 2014, the export of Indonesian's mens-apparel to the world reached 709 million US\$, decreasing by US $\$ 18$ million from the previous year, meanwhile export from Vietnam has increased by US\$396 million. The value of export to the seven EU countries during the crisis (2012) has declined, yet got better in the following year. In 2014, the value of exports grew by 9.2 percent.

Germany and Poland had the highest real GDP per capita growth i.e. 1.8 percent and 2.8 percent respectively, while the Spanish and Italy experienced a decline in real GDP per capita, and the rest countries increase from 0.08 to 0.3 percent. This increasing of GDP can be assumed to increase Indonesia's mens-apparel exports to EU export destinations.

\section{A. Comparative Competitiveness of Indonesia's and Vietnam's Mens-Apparel}

Competitiveness can be defined as the ability for a commodity to enter foreign markets and able to survive in that market [12]. There are two factors that determine the level of competitiveness of a commodity, namely comparative advantage and competitive advantage. Although a country is less efficient than other countries in producing commodities, both sides can still make profitable trades, for example, when a country specializes in the production and export of commodities with smaller absolute losses (commodities with comparative advantage), and imports 
commodities with greater absolute losses (commodities with comparative losses) [13]. Heckser-Ohlin stated that the comparative advantage will be influenced by the abundance of factors owned production.

RCA and EPD method have been used to analyze the competitiveness i.e. competitiveness of Indonesian and Vietnamese coffee exports in the ASEAN 5 market over the past fourteen years [14], competitiveness of Indonesian garment (HS 611020) to the main destination countries in 2009-2013 [15], and performance of Indonesian electronics exports to Latin America [16].

Table 1. shows that the value of RCA average of Indonesia's mens-apparel in all destination countries were more than one. This highlighted the high competitiveness, particularly in Belgium. During 2010-2014, the competitiveness always increase, except in Spain.

Table 1. RCA value of men's apparel of Indonesia

\begin{tabular}{|l|c|c|c|c|c|c|c|}
\hline Country & 2010 & 2011 & 2012 & 2013 & 2014 & $\begin{array}{c}\text { Ave- } \\
\text { rage }\end{array}$ & $\begin{array}{c}\text { Growth } \\
(\%)\end{array}$ \\
\hline Belgium & 2.82 & 3.66 & 8.29 & 7.94 & 11.01 & 6.74 & 0.48 \\
\hline France & 4.56 & 5.05 & 5.03 & 6.47 & 6.86 & 5.59 & 0.11 \\
\hline Germany & 4.89 & 5.80 & 3.38 & 3.39 & 5.23 & 4.54 & 0.08 \\
\hline Italy & 0.95 & 0.70 & 0.87 & 1.19 & 1.34 & 1.01 & 0.12 \\
\hline Netherland & 0.36 & 1.89 & 0.95 & 0.57 & 2.36 & 1.23 & 1.61 \\
\hline Spain & 1.36 & 2.39 & 1.05 & 0.79 & 0.66 & 1.25 & -0.05 \\
\hline Poland & 2.58 & 2.59 & 3.21 & 3.67 & 2.82 & 2.97 & 0.04 \\
\hline
\end{tabular}

Source: calculation by researcher

RCA value of mens-apparel from Vietnam in the same destination country (Table 2), were higher than Indonesia. Exporter from Indonesia has opportunity to improve its competitiveness, since Vietnam has negative growth of RCA.

Table 2. RCA value of men's apparel of Vietnam

\begin{tabular}{|l|c|c|c|c|c|c|c|}
\hline Country & 2010 & 2011 & 2012 & 2013 & 2014 & $\begin{array}{c}\text { Ave- } \\
\text { rage }\end{array}$ & $\begin{array}{c}\text { Growth } \\
(\%)\end{array}$ \\
\hline Belgium & 21.78 & 20.23 & 21.66 & 16.45 & 14.61 & 18.94 & -0.01 \\
\hline Germany & 10.97 & 9.34 & 8.88 & 9.05 & 9.95 & 9.64 & -0.02 \\
\hline France & 11.31 & 7.90 & 4.97 & 3.79 & 4.24 & 6.44 & -0.05 \\
\hline Italy & 6.18 & 4.62 & 2.58 & 3.15 & 3.79 & 4.06 & -0.04 \\
\hline Poland & 6.86 & 7.84 & 10.55 & 19.46 & 24.00 & 13.74 & 0.23 \\
\hline Spain & 10.62 & 9.50 & 5.01 & 5.49 & 6.14 & 7.26 & -0.04 \\
\hline Netherland & 10.33 & 12.78 & 15.91 & 10.47 & 10.72 & 12.04 & 0.06 \\
\hline
\end{tabular}

Source: calculation by researcher

\section{B. The Dynamics of Indonesian Men's Apparel Export to the EU Countries}

Indonesia's mens-apparel is in the Rising Star (RS) position only in Italy and Poland. Other countries were dominating the Falling Star (FS) position. There was a Retreat (R) position for the Spanish country (Table 3). The RS position is the most ideal position, indicating that the exporting country has gained additional market share in the mens-apparel which market demand grows fast. The FS position is not desirable, since the exporting-country market share has increased but the demand for the apparel declined. The $\mathrm{R}$ position is the most undesirable position, because both export market share and export demand was decreasing.
The overall market position of Vietnam's mens-apparel market in the same destination countries is in the Rising Star position, except in France which is in Lost Opportunity (Table 3). Lost Opportunity is the unwanted position, because there is a decrease in market share of men's apparel, while the demand is growing. Exporter country loses the opportunity to optimize a dynamic market for profit.

The lower competitiveness of Indonesia and the market position comparing to Vietnam were caused by several factors i.e.: (i) the industrial gas prices are more expensive; (ii) Vietnam provides tax relief on industries operating in the country; (iii) Vietnam's labor wages are proportional to the labor productivity, while Indonesia has the UMR that tends to increase annually but it is not accompanied by increases in productivity; (iv) Vietnam has a Partnership Cooperation Agreement with the EU and this cooperation has helped to increase the export of mens-apparel. By 2015, Vietnam and the EU have completed the free trade area (FTA) negotiations between the two parties. While the FTA negotiations between Indonesia and the EU in early 2017 only started to enter the second phase of negotiations.

Table 3. EPD of men's apparel in EU Countries

\begin{tabular}{|l|r|c|c|r|c|c|}
\hline \multirow{2}{*}{ Country } & \multicolumn{2}{|c|}{ Growth X $(\%)$} & \multicolumn{2}{|c|}{ Growth Y (\%) } & \multicolumn{2}{c|}{ Position } \\
\cline { 2 - 7 } Belgium & 44.57 & 6.39 & -2.84 & 17.22 & FS & RS \\
\hline Germany & 5.54 & 14.51 & -4.90 & 17.47 & FS & RS \\
\hline France & 4.13 & -4.04 & -3.98 & 21.39 & FS & LO \\
\hline Italy & 8.95 & 18.03 & 0.04 & 29.61 & RS & RS \\
\hline Poland & 162.48 & 59.19 & 0.17 & 17.46 & RS & RS \\
\hline Spain & -10.78 & 8.15 & -6.16 & 21.12 & R & RS \\
\hline Netherland & 1.45 & 21.88 & -1.55 & 17.69 & FS & RS \\
\hline
\end{tabular}

Ina: Indonesia; Viet: Vietnam

Source: calculation by researcher

\section{Factors Influencing Indonesia's Mens-Apparel Exports to EU Countries}

This study used gravity model to analyze the factors that influence the value of Indonesia's mens-apparel exports to the seven EU countries. The Gravity model has been used by [17] to predict factors affecting Nigeria's exports to BRICS member countries, nine members of EU, Canada, Japan and the United States, by [18] to explain the factors affecting bilateral trade between Vietnam and the twenty-three EU member states, by [19] to analyze the trade of Bangladesh with major countries. Based on the Chow test and Hausman test, the gravity model used in this research is fixed effect model.

Table 4. Coefficient of FEM with cross section weight

\begin{tabular}{|l|c|c|}
\hline \multicolumn{1}{|c|}{ Factor } & Coefficient & Probability \\
\hline Intercept & -91.27 & 0.0000 \\
\hline LnGDPcap $_{\mathrm{jt}}$ & $11.99^{* * *}$ & 0.0000 \\
\hline LnREER $_{\mathrm{jt}}$ & $6.662^{* *}$ & 0.0104 \\
\hline LnED $_{\mathrm{ijt}}$ & $-11.595^{* * *}$ & 0.0020 \\
\hline
\end{tabular}


Table 4, cont.

\begin{tabular}{|l|c|c|}
\hline LnPEX $_{\mathrm{t}}$ & $0.596^{* * *}$ & 0.0024 \\
\hline $\mathrm{QPI}_{\mathrm{i}}$ & $0.312^{* * *}$ & 0.0004 \\
\hline \multicolumn{3}{|c|}{ Weighted Statistics } \\
\hline $\mathrm{R}^{2}$ & 0.9844 \\
\hline Prob (F-statistic) & 0.0000 \\
\hline
\end{tabular}

$* * *$ significant at $1 \%$; ** significant at $5 \%$

Source: calculated by researcher

Table 4 shows the coefficient value of factors affecting Indonesia's men's-apparel export to the seven EU countries. Real GDP per capita of destination country, economic distance, export price, port quality and real effective exchange rate are significantly affect the value of Indonesia's mens-apparel exports to the seven EU countries. The value of $\mathrm{R}^{2} 0.9844$ indicated that 98.44 percent of mens-apparel export variance can be explained by independent variables in the model. Models of Indonesian men's apparel export are as follows (5):

$$
\begin{aligned}
& \text { LnEX } \\
& \text { 6.662 LnREER } \\
& \text { 0.312 LnQPI }-11.595 \text { LnED }_{i j t}+0.596 \operatorname{LnPEX} X_{i j t}+ \\
& \quad \text { Real GDP }
\end{aligned}
$$

Variable of Real GDP is used in gravity model. According to [6] to calculate country's prosperity better, it is favorable to use the value of output of goods and services which is not affected by price changes, and eliminate inflation factor [22]. Real GDP per capita (GDPcap) of destination country has significantly influenced mens-apparel in the level 11.990. Each percent increasing in real GDP per capita will increase 11.990 percent (ceteris paribus) of mensapparel export. Income elasticity of mens-apparel demand is higher than 1. This means that mens-apparel belongs to normal goods, in line with the study [20] which states that real GDP per capita of destination countries reflects the purchasing power of the resident. Increasing in real GDP lead to demand of import then increase Indonesia export.

\section{Real Exchange Rate}

According to [21] the exchange rate between the two countries is the price level agreed by the people of both countries to trade each other. The real exchange rate (REER) is the relative price of goods between the two countries. The real exchange rate specifies the rate at which it can trade goods from Indonesia for the goods of EU countries. Variable REER has a positive and significant correlation to the mens-apparel exports, with coefficient value is 6.662 . When the exchange rate of one-state increases, Indonesia's export of mens-apparel will increase by 6.662 percent. Increasing REER will push the price of domestic goods, while imported goods are cheaper. Increase in REER will increase in demand for Indonesian men's apparel [15] and [1].

\section{Economic Distance}

The economic distance (ED) of the two trading partners is a main variable in the gravity model. Distance is a proxy for calculating transportation costs [22]. Based on [23], the distance variables are replaced by the weighted average economic distance to indicate trade costs, since distance data shows only the physical distance between countries. Economic distance were calculated according to formula (6).

$$
E D_{i j t}=\text { Dist }_{i j} x \frac{\mathrm{GDPjt}}{\sum_{j=1}^{7} \mathrm{GDPjt}}
$$

Where, $\mathrm{ED}_{\mathrm{ijt}}$ : economic distance between exporting countries (i) and destination countries (j) in year $\mathrm{t}$; Dist $\mathrm{i}_{\mathrm{j}}$ : Geographical distance between exporting country and destination country; GDP $_{\mathrm{jt}}$ : The real GDP of each importing country in year $t$ (US\$); $\Sigma$ GDP $\mathrm{jt}_{\mathrm{jt}}$ : Total real GDP of all importing countries in year $\mathrm{t}$ (US\$)

The economic distance between Indonesia and destination countries negatively affects the value of export, with coefficient value of -11.595 . It means that when the economic distance increases by one percent, then the value of apparel exports will decrease by 11.595 percent. The economic distance reflects cost of transportation, so that the increasing economic distance is a form of increased transportation costs and it will reduce the value of trade [18].

\section{Export Price}

Price can affect both sides of supply and demand. The price have a positive effect on export offered by exporter, and will negatively affect the export demanded by the importer. An increase in price will cause overseas consumers to reduce the amount of demand for imported goods, so that the export volume of exporting countries will decline. If the export price decreases, it will increase export demand [23]. The general equation of prices is derived from the value of exports divided by export volume.

The coefficient value of export price (PEX) is 0.596, positively affect export value. The results are not in accordance with the initial hypothesis. If a price increase by one per cent, the increase in demand for Indonesia's mensapparel is by 0.596 per cent. The estimation results are in line with research [15] which stated that rising export commodity prices reflect the quality of its commodities. Then increasing prices will increase the export value of men's apparel exports in destination countries. In this study, export prices were obtained from the export value of mens-apparel divided by the export volume.

\section{Port Quality}

The Quality of port infrastructure (QPI) is a noneconomic variable that can be used to see the perception of the businessman to the port facility in a country. Port quality is an important factor to consider because it can determine the smoothness of the process of transporting traded goods. Variable of the quality of port infrastructure starts from the conditions of port infrastructure in the category of extremely underdeveloped (number one) up to the condition of port infrastructure is in an efficient category and has been in accordance with international standards (number 7). If there is an improvement in the quality of port of a country then it can affect the increase in state exports because the process of transporting goods become more efficient [23]. 
Based on the estimation result, Table 4 indicates that port quality has a significant positive effect on export value. Improvements in the quality of Indonesian ports by one percent will increase the value of Indonesia's mens-apparel exports by 0.312 percent. Study from [23] show that port efficiency influences transportation cost of one percent. The more efficient a port, the more it will reduce transportation costs and increase trade competitiveness.

\section{CONCLUSION AND SUGGESTION}

Indonesia's mens-apparel commodities have a comparative competitiveness in the EU market. Indonesia's market position was Rising Star in Italy and Poland. It was Retreat in Spanish, while in the other four countries were in the Falling Star position. This position is less competitive than Vietnam's commodities in the same market. The position of Vietnam's commodities as a whole were Rising Star in all countries. But in terms of performance improvement, during 2010-2014 there has been an increase in the comparative competitiveness of Indonesia's mensapparel. Factors affecting the export value of Indonesia's mens-apparel in EU market were GDP per capita, export prices, Indonesian port quality and economic distance and exchange rate. All factors have positive relationship to export value, except economic distance which has negative influence to export value.

The market should be maintained and should continue to increase are Belgium, Germany, Italy, and Poland. Belgium and Germany are prospective market since they have high population and GDP per capita. While in Italy and Poland, the position of mens-apparel market was Rising Star, with a positive growth of competitiveness. The Government can strive to continually improve the quality of Indonesian ports in order to achieve efficient delivery of exported goods then increase competitiveness of men's apparel.

\section{REFERENCES}

[1] Ministry of Industrial Government of Indonesia [Kementrian Perindustrian Republik Indonesia]. http//www.kemenperin.go.id February 2017

[2] [UNCOMTRADE] United Nations Comodity Trade Statistics Database. http://www.wits.worldbank.com. January, 2017.

[3] [WDI] World Development Indicator. http://data.worldbank.org., February 2017.

[4] [UNCTAD] United Nations Conference on Trade and Development. http://www.unctad.org. January, 2017.

[5] [CEPII] Centre d'Etudes Prospective et d'Informations Internationales Geodesic Distance http://www.cepii.fr/distance/dist_cepii.zip. February, 2017.

[6] Oktaviani R, Novianti T. Teori Perdagangan dan Aplikasinya di Indonesia. Bogor: Departemen Ilmu Ekonomi, Fakultas Ekonomi dan Manajemen, Institut Pertanian Bogor, 2014.

[7] Esterhuizen. Measuring and Analysing Competitiveness in The Agribusiness Sector: Methodological and Analytical Framework. Pretoria: University of Pretoria, 2006.

[8] Tinbergen J. Shaping The World Economy: Sugestions for an International Economic Policy. New York: Twentieth Century Fund Institute for International Economic Policy, 1962.

[9] Baltagi, B. H. Econometric Analysis of Panel Data, $3^{\text {rd }}$ ed. New York: John Wiley \& Sons. 2005.
[10] Firdaus M. Aplikasi Ekonometrika untuk Data Panel dan Time Series. Bogor (ID): IPB Press, 2011

[11] Jhingan ML. The Economic of Development and Planning. Vicas Publishing House Ltd, New Delhi, 1983.

[12] Porter ME. The Competitive Advantage of Nation. The Free Press, New York, 1990.

[13] Hossain, A. and Chowdhury, A. Open-Economy Macroeconomics for Developing Countries. Cheltenham UK: Edward Elgar 1998.

[14] Suharno, Zuhdi F. Analisis Daya Saing Ekspor Kopi Indonesia dan Vietnam di Pasar ASEAN 5. 26 (3): 152-162, 2015

[15] Listianingrum N. 2015. Posisi Daya Saing dan Faktor-Faktor yang Memengaruhi Ekspor Pakaian Jadi Indonesia ke Negara Tujuan UtamaTahun 2009-2013 [Skripsi]. Bogor (ID): Institut Pertanian Bogor, 2015.

[16] Hanoum FN. Analisis Kinerja Ekspor Elektronika Indonesia ke Amerika Latin [Skripsi]. Bogor (ID): Institut Pertanian Bogor, 2016.

[17] Shehu UR. Gravity Model by Panel Data Approach: Empirical Evidence from Nigeria. International Journal Trade and Global Markets, 8(1), 42-57, 2015.

[18] Do TT. A Gravity Model for Trade Between Vietnam and TwenyThree European Countries [Thesis]. Departement of Economics and Society, 2006.

[19] Rahman MM. A Panel Data Analysis of Bangladesh's Trade: The Gravitiy Model Approach [Thesis]. Sydney (ID): University of Sydney, 2006.

[20] Wardhani MA. Analisis Daya Saing dan Faktor-Faktor yang Memengaruhi Ekspor Ban Indonesia ke Amerika Latin [Skripsi]. Bogor (ID): Institut Pertanian Bogor, 2016.

[21] Dornbusch, R., S.Fischer, and R.Startz. . Macroeconomics, $9^{\text {th }}$ ed., McGraw-Hill, Boston. 2004.

[22] Krugman P, Obstfeld M. International Economics: Theory and Policy. Boston (ID): Pearson, 2003.

[23] Li K, Song L, Zhao X. Component Trade and China's Global Economic Integration.UNU-WINDER Research Paper 101:1-23, 2008. 